\title{
The Problem-Solving Skills Profile of Tsanawiyah Islamic School Students in the Vibration, Wave, and Sound Learning Materials
}

\author{
Mercury Nirwana ${ }^{1}$, Mohamad Nur ${ }^{2}$, Budi Jatmiko ${ }^{3}$ \\ 1,2,3 Postgraduate Program, Universitas Negeri Surabaya, Indonesia
}

\begin{tabular}{|c|c|}
\hline (A) Check for updates open $\partial_{\text {Access }}$ (c) (1) (2) & DOI : $\underline{\text { https://doi.org/10.46245/ijorer.v2i2.86 }}$ \\
\hline Sections Info & ABSTRACT \\
\hline Article history: & The purpose of this study is to determine the profile of problem- \\
\hline Submitted: January 24, 2021 & solving instruments which applied in Tsanawivah Islamic School on \\
\hline Final Revised: February 21, 2021 & vibration, waves, and sound learning materials based on the expert \\
\hline Accepted: March 21, 2021 & validation assessment and student's responses. This study used a pre- \\
\hline Published Online: March 31, 2021 & experimental design method, namely a one-shot case study and it was \\
\hline Keywords: & implemented in Tsanawiyah Islamic School. The sampling technique \\
\hline Profile problem-solving skills & used purposive sampling using one class. Data collections used \\
\hline Students responses & problem-solving skills instrument. The expert validation results \\
\hline The expert validation & showed that all of the instrument tests were very valid and it was \\
\hline Tsanawiyah Islamic School & declared fit for use. Student's responses from 15 questions were valid \\
\hline 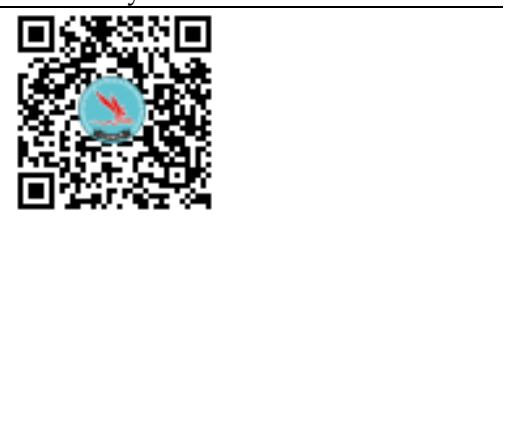 & $\begin{array}{l}\text { because the instrument tests have difficulty level with medium } \\
\text { category, although there was one number of the question has difficult } \\
\text { category. The distinguishing power showed a good and a very good } \\
\text { category although two numbers of questions were less categories. The } \\
\text { problem-solving skills profile in Tsanawiyah Islamic School showed a } \\
\text { good category in the expert validation noralthough student's responses } \\
\text { although there was a shortage. The limitation of the profile problem } \\
\text { solving skills was hindsight from expert validation and students } \\
\text { responses. The future research must be better and it can use } \\
\text { appropriate learning model for this research like Model SEA-MEA (Self } \\
\text { Efficacy Academic-Means Ends Analysis). }\end{array}$ \\
\hline
\end{tabular}

\section{INTRODUCTION}

Problem-solving skills are one of the thinking skills which needed in the $21^{\text {st }}$ century (Batlolona, 2018). Problem solving skills involve intellectual process of students to connect the old knowledge with the new knowledge to get problem solving (Arifuddin, 2017). Problem-solving skills use integrated thinking skills and basis of relevant knowledge (Nurhairani \& Dara, 2018). Students apply the knowledge and abilities to achieve goals in problem solving (Setyarini, 2021). Students must be used their experiences to solve problems (Tawfik, 2020). Students can get successful problem-solving when students have metacognitive experiences (Sengul, 2012). The habit of problem-solving in daily life is the achievement which compared to learning motivation (Chen, 2020). Problem-solving skills of students can measure by connecting information and testing hypothesis (Karyotaki, 2016).

Problem-solving skills help students to solve an issue (Tsankov, 2018). Problem-solving skills are needed in carrying out investigations (Mashluhah, 2018). Complex problemsolving makes students participate, provide non-cognitive skills, and critical life (Glazewski, 2020). The problem-solving skills of students in junior high school 1 Balongpanggang are still low categorized. The difficulty experienced in understanding 
problems obtained $51,61 \%$, difficulties in preparing problem formulation plans $80,65 \%$, difficulties in implementing problem-solving plans $48,39 \%$, and difficulties in re-checking students work results 51,61\% (Prastiwi, 2018).

Essay test of problem-solving can challenge students to solve these problems (Annisah, 2020). Essay test can make students get a good problem-solving (Toharuddin, 2017). Technology can be used in developing problem-solving skills of students (Kristanto, 2019). The online test of problem-solving can minimize the effect of language differentials (Vista, 2015). Problem solving skills profile of students by distributing tests using Google form in this research obtained a fairly good percentage. The representation indicator with understand problems sub-indicator obtained $40 \%$ with a sufficient category, execution with applying strategies for problem-solving sub-indicator obtained $37 \%$ with a sufficient category, execution with activating relevant knowledge sub-indicator got $53 \%$ with a good category, and planning in the utilizing relevant knowledge/experience sub-indicator obtained $40 \%$ with sufficient category. The purpose of this study is to determine the profile of problem-solving instruments applied in Tsanawiyah Islamic School on vibration, waves, and sound based on the validator's assessment and student's responses.

\section{RESEARCH METHOD}

This research used pre-experimental design method, especially one-shot case study and implemented in Tsanawiyah Islamic School. The instrument test has checked by two validators. Then, the instrument test shared to students by link Google form and then the result analyzed by AnatesV4. The sampling technique used purposive sampling using one class. The population in this research is students of VIII class in Tsanawiyah Islamic School Bangkalan. Samples of this research are 15 students of Tsanawiyah Islamic School Bangkalan especially VIII A. Data collections in this research used problem-solving skills instrument. The criteria of validation result explain in Table 1 and counting by 1.1 formula

$$
\mathrm{R}=\frac{s}{N} \times 100 \%
$$

Information:

Source: (Widoyoko, 2017)

$\mathrm{R} \quad=$ Average score

$\mathrm{S} \quad=$ Number of scores obtained

$\mathrm{N} \quad=$ Maximum number of scores

After knowing the value of each expert validity, then combined the expert validity results and analyzed all of the expert validators using 1.2 formula

$$
\mathrm{M}_{\mathrm{R}}=\frac{\sum R}{N}
$$

Information:

Source: (Sudijono, 2017)

$\mathrm{M}_{\mathrm{R}}=$ Average combined score

$\sum R=$ Number of scores obtained

$\mathrm{N}=$ The number of validators

The instrument has validly categorized if the instrument measures the mastery abilities in measured domain (Arifin, 2017). Instrument in this research has valid category after reaching more than $50 \%$ and the instrument is suitable for use (Riduwan, 2014). 
Table 1. Criteria of validity coefficient.

\begin{tabular}{ll}
\hline \multicolumn{1}{c}{ Validity coefficient } & \multicolumn{1}{c}{ Criteria } \\
\hline $75 \leq \mathrm{VC} \leq 100$ & Very valid \\
$50 \leq \mathrm{VC}<75$ & Valid \\
$25 \leq \mathrm{VC}<50$ & Enough Valid \\
$0 \leq \mathrm{VC}<25$ & Less Valid \\
\hline
\end{tabular}

Source: (Riduwan, 2014)

The instrument test was also limited test to 15 Tsanawiyah Islamic School students and analyzed students responses for multiple-choice and essay tests using the Anates application. To find out the distinguishing power of the items, use 1.3 formula with the distinguishing power criteria in the Table 2 and for the difficulty level of items use 1.4 formula with the difficulty level criteria in the Table 3.

$\mathrm{DP}($ essay test $)=\frac{\mathrm{SA}-\mathrm{SB}}{\mathrm{IA}}$ atau DP $($ objective test $)=\frac{\mathrm{JB}_{\mathrm{A}}-\mathrm{JB}_{\mathrm{B}}}{\mathrm{Js}_{\mathrm{A}}}$

$$
\left.T K(\text { essay test })=\frac{S A+S B}{I A+I B} \text { atau TK (objective test }\right)=\frac{J B_{A}+J B_{B}}{2 \cdot J s_{A}}
$$

Information:

Source: (Sundayana, 2016)

$\mathrm{SA}=$ Total score for the top group

$\mathrm{SB}=$ Total score for the lower group

$\mathrm{IA}=$ Total ideal score for the upper group

$\mathrm{IB}=$ Total ideal score for the lower group

$\mathrm{JB}_{\mathrm{A}}=$ The number of students in the upper group who answered correctly

$\mathrm{JB}_{\mathrm{B}}=$ The number of students in the lower group who answered correctly

$\mathrm{JS}_{\mathrm{A}}=$ The number of students in the upper group

Table 2. Distinguishing power criteria.

\begin{tabular}{ll}
\hline Distinguishing Power Coefficient & \multicolumn{1}{c}{ Criteria } \\
\hline $\mathrm{DP} \leq 0,00$ & Very bad \\
$0,00<\mathrm{DP} \leq 0,20$ & Bad \\
$0,20<\mathrm{DP} \leq 0,40$ & Enough \\
$0,40<\mathrm{DP} \leq 0,70$ & Good \\
$0,70<\mathrm{DP} \leq 1,00$ & Very good \\
\hline & \multicolumn{1}{c}{ Source: (Sundayana, 2016) }
\end{tabular}

Table 3. Difficulty level criteria.

Difficulty Level Coefficient

$\begin{array}{ll}\mathrm{TK}=0,00 & \text { Very difficult } \\ 0,00<\mathrm{TK} \leq 0,30 & \text { Difficult } \\ 0,30<\mathrm{TK} \leq 0,70 & \text { Enough } \\ 0,70<\mathrm{TK} \leq 1,00 & \text { Easy } \\ \mathrm{TK}=1,00 & \text { Very easy }\end{array}$

RESULTS AND DISCUSSION

Table 4. Expert validation results of instrument test.

\begin{tabular}{lr}
\hline \multicolumn{1}{c}{ Validation aspects } & Validation result \\
\hline IJORER: $h$ ttps:/journal.ia-education.com/index.php/ijorer & 160
\end{tabular}




\begin{tabular}{lc}
\hline \multicolumn{1}{c}{ Validation aspects } & Validation result \\
\hline The suitability questions with the aspects & $97 \%$ \\
Tables and figures related to problems & $92 \%$ \\
Does not give a double interpretation rise & $86 \%$ \\
The formulation of the sentences is clear & $89 \%$ \\
Do not depend on the previous problem & $95 \%$ \\
Communicative & $88 \%$ \\
\hline
\end{tabular}

This study conducted to determine problem-solving test validity. The validation of the problem-solving test was carried out by science's teacher of junior high school. The validation aspects of problem-solving test explained in Table 4 which shows that each aspect has very valid level of validity. The results of validation in the suitability questions with the aspects are $97 \%$ very valid category, the second aspect is tables and figures related to problems got $92 \%$ very valid category, the third aspect does not give a double interpretation rise got $86 \%$ very valid category, the fourth aspect is the formulation of the sentences is clearly obtained $89 \%$ very valid category, the fifth aspect do not depend on the previous problem obtained $95 \%$ very valid category, and the last aspect is communicative obtained $88 \%$ very valid category.

Table 5. Expert validation results of 15 questions.

\begin{tabular}{cc}
\hline Number of Test & Validation results \\
\hline 1 & $94 \%$ \\
2 & $93 \%$ \\
3 & $91 \%$ \\
4 & $91 \%$ \\
5 & $81 \%$ \\
6 & $94 \%$ \\
7 & $96 \%$ \\
8 & $89 \%$ \\
9 & $85 \%$ \\
10 & $89 \%$ \\
11 & $92 \%$ \\
12 & $96 \%$ \\
13 & $77 \%$ \\
14 & $91 \%$ \\
15 & $91 \%$ \\
\hline
\end{tabular}

Based on Table 5, there are expert validation results of 15 instrument tests and all of validation results showed that the instrument test is very valid in accordance with validity coefficient's criteria in the Table 1 which have value range $75 \%-100 \%$. The expert validation results showed that the instrument test can share to students. The results of trials instrument test to 15 students through Google Form were analyzed by AnatesV4 application. Online problem-solving tests can minimize the effect of language differentials (Vista, 2015). The test analysis of the distinguishing power, difficulty level of the test, and the correlation of the test carried out online are presented in Table 6. 
Table 6. The Results of instrument test analysis in 15 questions.

\begin{tabular}{ccccccc}
\hline $\begin{array}{c}\text { Number } \\
\text { of } \\
\text { question }\end{array}$ & $\begin{array}{c}\text { The } \\
\text { distinguishing } \\
\text { power }\end{array}$ & Category & $\begin{array}{c}\text { The } \\
\text { difficulty } \\
\text { level of } \\
\text { the } \\
\text { question }\end{array}$ & Category & $\begin{array}{c}\text { The } \\
\text { correlation }\end{array}$ & Category \\
\hline 1 & $-0,25$ & Less & 0,33 & Medium & $-0,24$ & - \\
2 & 0,25 & Medium & 0,33 & Medium & 0,12 & - \\
3 & 1 & Very good & 0,40 & Medium & 0,82 & Very significant \\
4 & 0,75 & Very good & 0,33 & Medium & 0,59 & Significant \\
5 & 1 & Very good & 0,53 & Medium & 0,71 & Very significant \\
6 & 1 & Very good & 0,47 & Medium & 0,90 & Very significant \\
7 & 1 & Very good & 0,40 & Medium & 0,72 & Very significant \\
8 & 0 & Less & 0,20 & Difficult & 0,26 & - \\
9 & 1 & Very good & 0,53 & Medium & 0,81 & Very significant \\
10 & 1 & Very good & 0,40 & Medium & 0,88 & Very significant \\
11 & 0,76 & Very good & 0,51 & Medium & 0,83 & Very significant \\
12 & 0,63 & Good & 0,38 & Medium & 0,72 & Significant \\
13 & 0,56 & Good & 0,32 & Medium & 0,61 & Significant \\
14 & 0,73 & Good & 0,46 & Medium & 0,91 & Very significant \\
15 & 0,93 & Very good & 0,53 & Medium & 0,87 & Very significant \\
\hline
\end{tabular}

The difficulty level of the questions is a number that indicates the difficulty or easy questions for the students. Good questions are neither easy nor difficult. Easy questions do not stimulate students to enhance their efforts to solve a problem. Difficult questions cause students to despair and they have not eager to try again because they are out of reach, so students problem-solving being considered difficult and the answered is not according to the answer's key (Arikunto, 2012).

An analysis result of difficulty level and distinguishing power are very important to find out the success level of questions in measuring student's actual abilities. The difficulty level or distinction which is not good causes the problem is not able to measure student's abilities with good category. Items cannot state the difference of distinguish student's abilities, which have incorrect answers key, items have two correct answer keys, the competency measured unclear, the deception does not work, the material is too difficult for students so guess the answer, and some students are thinking that there is a piece of error information in the items, so they choose incorrect answers (Solichin, 2017).

Student's answers in the essay test were varied, even the answers "don't know". The weakness of the essay test is the lack of student's ability to understand the content or the student's inconsistency in translating the item test so that the test is not accurate. However, the advantage of this essay test is easy to arrange questions on the test (Yusuf, 2015). The problem-solving essay test can challenge students to solve these problems and provide alternative correct solutions (Annisah, 2020). The problem-solving essay test obtained good categories (Toharuddin, 2017). Examples of indicators that are difficult to answer correctly by students on multiple-choice tests based on Table 6 are the execution indicator in apply strategies for problem-solving sub-indicator. The indicator is difficult category with the lowest percentage, 0,20 , and also have the distinguishing power of the test with fewer 
categories. The material is too difficult for students so the students guess the answer (Solichin, 2017). The difficulty level of the test is also caused by the complexity of the test subject and the condition of the answer choices because the test often presents confuse students and the alternative answers is also homogeneous or the sentences is too difficult to understand (Hanifah, 2014).

The lowest difficulty level has the lowest distinguishing power. It means each question has a small chance to get the different values of students. The item is the best if it got 0,50 with maximum difficulty level. It means, only half of the testers give the correct answers. If the difficulty level reaches $0,25-0,75$, the distinguishing power of the problem is high. The good items are neither difficult nor easy (Yusuf, 2015).

The distinguishing power used to know the difference of mastered competence's student based on certain criteria. The higher coefficient in the distinguishing items can distinguish the students who have master competencies. When distinguishing power in the question of number 8 obtained low categories with zero value based on Table 6 , so the questions cannot distinguish between the students who have good competencies and fewer competencies (Arifin, 2017).

Other factors that can affect the student's grade in answering questions are the student's initial ability, student's concentration when they solved a problem, and time working the questions. Physics learning is still difficult for some students because students have poor initial Physics abilities, for example in the vibrations, waves, and sounds learning materials (Veronica, 2018). There are internal and external factors, which have effect the achievement of the material (Kallesta, 2017). The external factors from students were 1) the teacher gave less motivation and learning resources was less support 2) time of the lesson was conducted during the daytime so students become less enthusiastic and lazy to learn. Questions, which are done during the day make students less concentrated, so they have less enthusiastic in working on the questions and they answer in moderation. According to validators, questions of problem-solving are easy, but students said "it is difficult." This indicated that the results of the teacher validations with student test gave different result. There are many students who cannot answer the questions even though validators said the instrument test is very valid categorized. The understanding and experiences of the validators and students are so different, so the results are also different. The multiple-choice test was also analyzed with the quality of deception, which representation in Table 7.

Table 7. The quality of spoofing each the questions.

\begin{tabular}{ccccc}
\hline $\begin{array}{c}\text { Number of } \\
\text { questions }\end{array}$ & A & B & C & D \\
\hline 1 & $0--$ & $5^{* *}$ & $2+$ & $8--$ \\
2 & $5^{*}$ & $7---$ & $0--$ & $3++$ \\
3 & $3++$ & $2+$ & $4+$ & $6^{* *}$ \\
4 & $5+$ & $3++$ & $2+$ & $5^{* *}$ \\
5 & $8^{* *}$ & $3+$ & $3+$ & $1-$ \\
6 & $3++$ & $7^{* *}$ & $2+$ & $3++$ \\
7 & $1-$ & $4+$ & $4+$ & $6^{* *}$ \\
8 & $7-$ & $4++$ & $3^{* *}$ & $1-$
\end{tabular}

Information:

** : Answer's key

++ : Very good

$+:$ Good

- : Less

-- : Bad

--- : Very bad 


\begin{tabular}{ccccc}
\hline $\begin{array}{c}\text { Number of } \\
\text { questions }\end{array}$ & A & B & C & D \\
\hline 9 & $3+$ & $8^{* *}$ & $1-$ & $3+$ \\
10 & $6^{* *}$ & $3++$ & $4+$ & $2+$ \\
\hline
\end{tabular}

Based on Table 7, there are the various deceptive qualities from a very poor category to a very good category. The best deception quality obtained by answer B in question number 8 . There are 4 students choose that answer. A very poor quality of deception occurred in answer $\mathrm{D}$ in question number 1 with 8 students who choose that answers. The effectiveness of deceit can be known by looking at the pattern of the answer distributions from students. The pattern of answer distribution is obtained by counting the number of tester who chose the answer's choice or they did not choose anything. The students who are fooled, they indicated that the quality of their deception is very good. Deception is functioning well if the voter answers at least $5 \%$ (Arikunto, 2012). A better deception, it means a better quality of the problem. So, the deception is a benchmark to see the difference between smart students and less smart students.

Student's problem attitudes are positively correlated with student's perceptions regarding their knowledge and increased thinking skills as a result of participating (Huang, 2016). The student's problem-solving abilities lie in how students use knowledge by connecting one concept to one another (Dewi, 2017). Students are successful in problemsolving when they have metacognitive experiences (Sengul, 2012). A good metacognition experience will be result in good problem-solving. Students problem-solving skills must be measured from students cognitive and metacognitive skills in connecting information and testing hypotheses (Karyotaki, 2016). Students are still individual so they have less cooperate with other students and it caused students problem-solving abilities were not maximal (Dewi S., 2016). Metacognition helped group members to solve the redesign problem instructional, especially awareness of meta social related to the expertise of other members, monitoring of understanding, and monitoring of processes (Siegel, 2012).

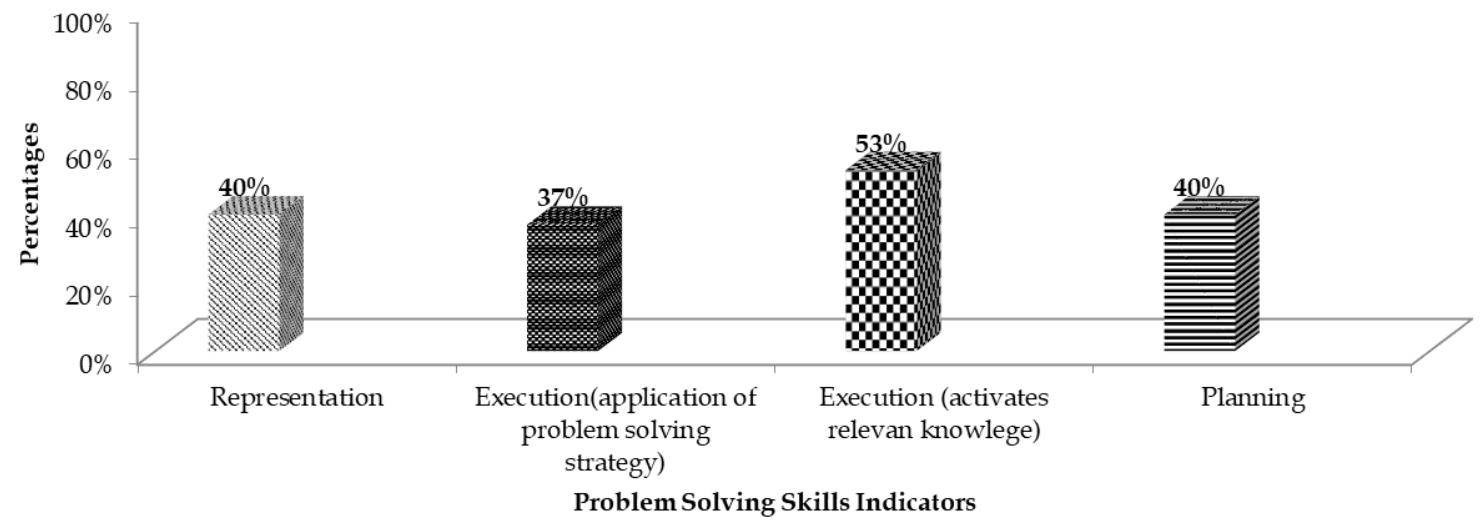

Figure 1. The diagram of the instrument test result based on problem-solving skills indicators.

Based on figure 1, There are 3 problem-solving indicators which are representation, execution, and planning. The sub-indicators of problem-solving skills indicators could be seen in the Table 8. 
Table 8. Problem-Solving Skills Indicator

\begin{tabular}{ll}
\hline \multicolumn{1}{c}{ Indicators } & \multicolumn{1}{c}{ Sub-indicators } \\
\hline Representation & Understanding the problem \\
Planning & Utilizing relevant knowledge/experience \\
Execution & - Applying a strategy for problem-solving \\
& - Activates relevant knowledge \\
\hline
\end{tabular}

Source: (Curtis, 2003)

An execution indicator in activates relevant knowledge sub-indicator got a good category, so students have not very good problem-solving skills. The first indicator is representation with sub-indicator understanding the problem. The examples questions of representation indicator lie in the question of number 1 that students investigate the pendulum vibration event with a different angle. Figure 1 showed that the indicator obtained $40 \%$ which is quite capable of understanding the problem. The second indicator is the execution in the sub-indicator of applying a strategy for problem-solving which students were given mathematical problems in this indicator. The percentage of this indicator was $37 \%$ which is quite capable of applying mathematical problem-solving strategies such as formulating the frequency and period of vibration's connection. Students of secondary education often find difficult to apply Mathematics in Physics (Tursucu, 2020). The research stated that students have not basic algebraic skills, so students are having difficulty in mathematical problem-solving. The third indicator is the execution which in activates relevant knowledge sub-indicator obtained $53 \%$ in a good category where it lies in question of number 5 with the question indicator is explaining the occurrence of sound waves by distinguishing louder sounds when it was chatting at night than the day. That question activates relevant knowledge of students in their daily lives. The habit of problem-solving in daily life is the center of achievement compared to learning motivation (Chen, 2020). The last indicator is planning with utilizing relevant knowledge/experience sub-indicators obtained $40 \%$ which is quite capable of linking or utilizing relevant knowledge or experience. This indicator is in the question of number 10 with indicator question is explaining the mechanism of the humans listening using a telephone from the jumble.

Based on Figure 1 and the description above, student's problem-solving indicator are not good categorized because students did not understand the problem-solving process. A finding showed that context-based learning can effectively build student's problem-solving processes $(\mathrm{Yu}, 2015)$. Students are studying and able to solve problems well when they understand what is learned by Gestalt's theory (Mujtahidin, 2014). The statement is related to this research and students can solve problems when the students understand both the problem formulation and the hope of problem-solving. The learning design which used by teachers can give effect to student's problem-solving skills (Akma, 2018). Complex problem-solving is a way to build students participation in content, provide non-cognitive skills and critical life (Glazewski, 2020).

Ausubel's meaningful theory can support problem-solving which stated that meaningful learning occurs when the students are linking new information with relevant concepts in one's cognitive structure (Mujtahidin, 2014). Students who have previously learned about the hearing system in animals, then students expected to link the previously 
information with new information in the sound waves precisely the sonar working system in dolphins. Students who can solve problems by linking the dolphin hearing system with sound waves can be said that they have meaningful experienced learning by Ausubel's theory. Students can use their experience to solve new problems (Tawfik, 2020). Students problem-solving abilities need to train continuously in order to students can solve their problems. Strong guidance can give a positive impact in student's problem-solving skills (Atmatzidou, 2018). Problem-solving abilities can be a provision for solving problems in everyday life (Putra, 2020).

Student groups are divided into two, there are students who have skilled in problemsolving and students who have less skilled in problem-solving (Theasy, 2018). Students who have problem-solving skill used non-mathematical representations, such as charts, graphs, and diagrams, while students who have less problem-solving skill tend to use mathematical representations. Science learning which applies multiple representations can provide opportunities for students to understand concepts and communicate them well (Bahaudin, 2019). Many factors which are affect students problem-solving abilities are selfconfidence, determination, sincerity, and students persistence in finding problem solutions (Theasy, 2018). Students who have high self-efficacy showed that they have persistence and ability to solve difficult problems (Citra, 2020).

Problem-solving skills improve after using the PBL approach (Anantasuk, 2019). The PBL model can improve student's problem-solving skills and science learning outcomes if implemented with a scientific approach (Cahyani, 2019). Learning which is using a scientific approach by utilizing quantum learning strategies can also optimize students problem-solving skills and regulated learning (Sudirman, 2017). Problem-solving strategies are also effectively used for communication skills, creativity, problem-solving, and students mathematical reasoning abilities (Tambunan, 2019). Student's problem-solving abilities have increased after using skills-based learning models (Ijirana, 2019). Student's problem-solving skills in science learning are sufficiently categorized after using distance learning through online tutorials with interactive discussions (Widiasih, 2018). Exploration of each student's problem-solving can be done using an instructional design model that aims to develop student's real world problem-solving (Zhong, 2019).

\section{CONCLUSIONS}

The expert validation results showed that all of the instrument tests were very valid and it was declared fit for use. Student's responses from 15 questions were valid because the instrument tests have difficulty level with medium category, although there was one number of the question has difficult category. The distinguishing power showed a good and a very good although two numbers of questions were less categories. The limitation of the profile problem solving skills was hindsight from expert validation and students responses. The future research must be better and can use appropriate learning model for this research like Model SEA-MEA (Self Efficacy Academic-Means Ends Analysis).

\section{ACKNOWLEDGEMENTS}

We say thank you to students of Tsanawiyah Islamic School Bangkalan especially VIII-A class who gave me chance to do this research. We say thank you for everyone who gave me support for this research. 


\section{REFERENCES}

Akma, T. (2018). The design of student worksheet problem based learning to improve problem-solving ability of the eighth-grade students junior high school in Indonesia. International Journal of Engineering \& Technology, 11-15.

Anantasuk, N. (2019). Effects of problem-based learning approach on problem-solving skills and cooperative working ability of eighth-grade students. International Journal of Social Sciences, 4(3), 1277-1284.

Annisah, S. Z. (2020). Test instrument development of mathematical problem solving skills. International Journal of Advance Science and Technology, 29(6), 1483-1492.

Arifin, Z. (2017). Kriteria instrumen dalam suatu penelitian. Jurnal THEOREMS (The Original Research of Mathematics), 2 (1), 28-36.

Arifuddin, M. M. (2017). Improving problem solving skill in physics through argumentation strategy in direct instruction model. International Journal of Sciences: Basic and Applied Research, 35 (3), 348-353.

Arikunto, S. (2012). Dasar-dasar evaluasi pendidikan. Jakarta: Bumi Aksara.

Atmatzidou, S. D. (2018). How does the degree of guidance support students metacognitive and problem-solving skills in education robotics? Journal of Science Education and Technology, 27, 70-85.

Bahaudin, A. F. (2019). Validity of physics learning module based on multirepresentation to improve the problem-solving ability. IOP Conference Series Journal of Physics: Conference Series 1185.

Batlolona, J. R. (2018). The improvement of problem-solving skills and physics concept mastery on temperature and heat topic. Jurnal Pendidikan IPA Indonesia, 7(3), 273-279.

Cahyani, E. S. (2019). Effectiveness of the saintifical approach to the ability of problem based learning model solving the problem and the results of student learning in natural knowledge science in basic school. International Journal of Scientific and Research Publications, 9(8), 937-941.

Chen, S.-Y. \&.-W. (2020). A cross-cultural study of mathematical achievement: from the perspective of one's motivation and problem-solving style. International Journal of Science and Mathematics Education, 18, 1149-1167.

Citra, C. D. (2020). The practicality and effectiveness of multiple representations based teaching material to improve student's self-efficacy and ability of physics problemsolving. IOP Conference Series: Journal of Physics: Conference Series 1467.

Curtis, D. \&. (2003). The autentic performance-based assessment of problem solving. King William Road: NCVER.

Dewi, I. S. (2017). Elsii learning model based local wisdom to improve students problemsolving skills and scientific communication. International Journal of Education and Research, 5(1), 107-118.

Dewi, S. (2016). Penerapan model pembelajaran pbl untuk meningkatkan keaktifan dan keterampilan sosial siswa kelas v sdn tangkil 01 Wlingi. Jurnal Pendidikan, Teori, Penelitian, dan Pengembangan, 1(3), 281-288. 
Glazewski, K. D. (2020). Fostering complex problem solving for diverse learners: engaging an ethos of intentionally toward equitable access. Educational Technology Research and Development, 68 , 679-702.

Hanifah, N. (2014). Perbandingan tingkat kesukaran, daya pembeda butir tes dan reliabilitas tes untuk bentuk pilihan ganda biasa dan pilihan ganda asosiasi mata pelajaran ekonomi. Sosio e-KONS, 6(1) , 41-55.

Huang, N.-T. N.-J.-C. (2016). Relationship among student's problem-solving attitude, perceived value, behavioral attitude, and intention to participate in a science and technology contest. International Journal of Science and Mathematics Education, 14, 1419-1435.

Ijirana, L. N. (2019). Time series study of problem-solving ability of Tadulako university students using metacognitive skill based learning model. iJET, 14(21), 227-234.

Kallesta, K. S. (2017). Analisis Faktor penyebab kesulitan belajar ipa fisika pada materi bunyi. Jurnal Pendidikan Fisika, 1(1).

Karyotaki, M. \&. (2016). Online and other ICT-Based asessment tools for problem solving skills. iJET, 11 (4), 56-60.

Kristanto, A. S. (2019). Promoting local wisdom in international primary curriculum aims to develop learner's problem solving skills. International Journal of Educational Research Review, 4(3), 439-447.

Mashluhah, M. P. (2018). The effectiveness of OrDeP2E learning model to train the natural science problem-solving skills of primary school students. IOP Conference Series: Journal of Physics: Conference Series 1157.

Mujtahidin. (2014). Teori belajar dan pembelajaran. Surabaya: Pena Salsabila.

Nurhairani \& Dara, G. A. (2018). Efektivitas model pembelajaran problem based learning terhadap kemampuan pemecahan masalah siswa pada mata pelajaran IPA di SD negeri 101800 Deli Tua T.A. 2017/2018. Jurnal Guru Kita, 2(3), 1-7.

Prastiwi, M. D. (2018). Kemampuan pemecahan masalah pada siswa kelas VII SMP. ejournal-pensa, 6(2), 98-103.

Putra, L. I. (2020). Design of student worksheet to PBL learning model to improve problem-solving skills. International Journal of Scientific E Technology Research, 9(3), 4967-4973.

Riduwan. (2014). Dasar-dasar statistika. Bandung: Alfabeta.

Sengul, S. K. (2012). Metacognitive aspects of solving function problems. Procedia Social and Behavioral Science (Elsevier), 46, 2178-2182.

Setyarini, D. A. (2021). Improving senior high school students. International Journal of Recent Educational Research, 2(1), 42-53.

Siegel, M. A. (2012). Filling in the distance between us: group metacognition during problem-solving in a secondary education course. Journal of Science Education and Technology, 25, 325-341.

Solichin, M. (2017). Analisis daya beda soal, taraf kesukaran, validitas butir tes, interpretasi hasil tes dan validitas ramalan dalam evaluasi pendidikan. Jurnal Manajemen $\mathcal{E}$ Pendidikan Islam, 2(2), 192-213.

Sudijono, A. (2017). Pengantar statistik pendidikan. Jakarta: PT Raja Grafindo Persada. 
Sudirman, M. S. (2017). Improving problem-solving skills and self-regulated learning of senior high school students through scientific approach using quantum learning strategy. International Journal of Science and Applied Science: Conference Series, 2(1), 249255.

Sundayana, R. (2016). Statistika penelitian pendidikan. Bandung: Alfabeta.

Tambunan, H. (2019). The effectiveness of the problem-solving strategy and the scientific approach to student's mathematical capabilities in high order thinking skills. International Electronic Journal of Mathematics Education, 14(2), 293-302.

Tawfik, A. A. (2020). Effects of case library recommendation system on problem solving and knowledge structure development. Educational Technology Research and Development, 68, 1329-1353.

Theasy, Y. W. (2018). Multirepresentation ability of students on the problem-solving physics. IOP Conference Series: Journal of Physics: Conference Series, 983, 1-4.

Toharuddin, U. (2017). Critical thinking and problem solving skills: How these skilss are needed in educational psychology. International Journal of Science and Research, 6(3), 2004-2007.

Tsankov, N. (2018). The transversal competence for problem-solving in cognitive learning. International Journal of Cognitive Research in Science, Engineering and Education, 6(3), 67-82.

Tursucu, S. S. (2020). Search for symbol sense behavior: students in upper secondary education solving algebraic physics problems. Research in Science Education, 50, 21312157.

Veronica, T. S. (2018). Pengaruh pembelajaran dengan model problem-solving fisika terhadap hasil belajar dan kemampuan pemecahan masalah siswa kelas XI IPA SMAN 1 Lebong. Jurnal Kumparan Fisika, 1(2), 31-39.

Vista, A. E. (2015). Development of an online test of problem solving ability that minimises the extraneous differential effects of language background and subsequent validation through a large-scale DIF Analysis. International Journal of Educational Research, 69, 71-87.

Widiasih, A. P. (2018). The profile of problem-solving ability of students of distance education in science learning . $4^{\text {th }}$ International Seminar of Mathematics, Science, and Computer Science Education Series 1013.

Widoyoko, E. (2017). Teknik penyusunan instrumen penelitian. Yogyakarta: Pustaka Pelajar.

Yu, K.-C. F.-C.-Y. (2015). Enhancing students problem-solving skilss through context-based learning. International Journal of Science and Mathematics Education, 13, 1377-1401.

Yusuf, M. (2015). Asesmen dan evaluasi pendidikan. Jakarta: Kencana Prenadamedia Group.

Zhong, L. \&. (2019). Developing real life problem-solving skills through situational design: a pilot study. Educational Technology Research and Development, 67, 1529-1545.

* Mercury Nirwana (Corresponding Author)

Postgraduate Program, Science Education

Universitas Negeri Surabaya

Jl. Lidah Wetan, Surabaya, Jawa Timur, Indonesia

Email: mercury.19002@mhs.unesa.ac.id

IJORER: https://journal.ia-education.com/index.php/ijorer 
Prof. Dr. Mohamad Nur

Postgraduate Program, Science Education

Universitas Negeri Surabaya

Jl. Lidah Wetan, Surabaya, Jawa Timur, Indonesia

Email: mohamadnur.unesa@gmail.com

\section{Prof. Dr. Budi Jatmiko}

Postgraduate Program, Science Education

Universitas Negeri Surabaya

Jl. Lidah Wetan, Surabaya, Jawa Timur, Indonesia

Email: budijatmiko@unesa.ac.id 